\title{
REGIONALNA IDENTITETA V SLOVENIJI
}

\author{
dr. Danilo Kosi
}

Trnovska ulica 6, SI-I000 Ljubljana

e-mail: popetre@jvvz.org

Izvirni znanstveni članek

COBISS 1.01

DOI: 10.4312/dela.39.6.107-124

\section{Izvleček}

Prispevek obravnava različne vidike regionalne identitete. Nastajajo in se ohranjajo tudi z družbenim delovanjem, ki poteka skozi različne dejavnosti družbenega življenja. Te se pogosto odvijajo v prostorsko zaokroženih območjih, povzročajo diferenciranost prostora in občutek skupne regionalne pripadnosti. Namen članka je nakazati vzroke regionalne identitete in kakšne so njene posledice v prostorskih strukturah. Ena izmed posledic je lahko tudi pojav identitetnih regij.

Ključne besede: regija, regionalna identiteta, regionalna pripadnost, regionalna zavest, identitetna regija

\section{REGIONAL IDENTITY IN SLOVENIA}

\begin{abstract}
The paper is dealing with various aspects of regional identity. Regional identities are established and maintained with social functioning, passing through different spheres of social activities. All these activities are present in spatially integrated areas, causing differentiation of space and creating the sense of common regional belonging. The purpose of this article is to present the causes of regional identity and its consequences in spatial structures. One of the consequences could be the appearance of identity regions.
\end{abstract}

Key words: region, regional identity, regional belonging, regional consciousness, identity region 


\section{UVOD}

$\mathrm{V}$ tej raziskavi nam prostorska identiteta predstavlja širši pojem, znotraj katerega lahko umestimo identitete različnih prostorskih nivojev in eden od teh je na nivoju regije. Tako je ena izmed oblik prostorske identitete tudi regionalna identiteta. S teorijo regionalnih identitet se je podrobneje ukvarjal Paasi (1986), ki jo deli na identiteto regije in regionalno zavest. Pod pojmom 'identiteta regije' razumemo prevladujoče naravne in družbene značilnosti, ki so splošne priznane, prepoznavne in specifične za določeno regijo, ' regionalna' zavest pa je posameznikovo dojemanje prostora.

Slika 1: Regionalna identiteta po Paasiju (1986)

Figure 1: Regional identity according to Paasi (1986)

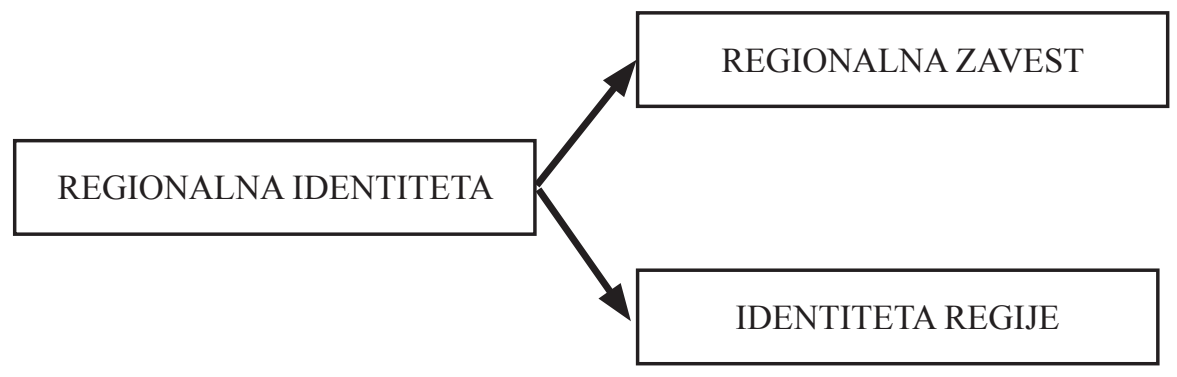

Namen prispevka je preučiti določene vidike regionalne identitete: sprašujemo se, kaj so vzroki njenega nastanka in ali ima ta pojav posledice tudi v prostorskih strukturah? Regionalna identiteta predstavlja izhodišče raziskave, $v$ kateri ugotavljamo, ali je ta pojav plod nekih imaginarnih predstav, ali pa jo lahko povežemo tudi z racionalnimi vplivi iz vsakdanjega življenja. Postavlja se vprašanje, kaj regionalno identiteto ustvarja in ohranja in ali je možno to tudi empirično dokazati? Vprašanje je tudi, ali je lahko ena izmed posledic regionalne identitete pojav identitetnih regij.

\section{I.I. Pregled literature}

Pregled literature na temo regionalne identitete je pokazal, da razen v sklopu drugih del, ni nobenega temeljitega samostojnega dela o njej. Paasi (1986) se ukvarja s teoretičnimi pristopi, ostali avtorji pa s posameznimi vidiki različnih prostorskih identitet (regionalna je ena izmed njih). To tematiko smo poskušali čim bolj celostno obravnavati v doktorski disertaciji (Kosi, 2012). Podrobnejših analiz v literaturi nismo zasledili.

Z različnimi prostorskimi identitetami so se mdr. ukvarjali naslednji slovenski raziskovalci: A. Černe, J. Zupančič, M. Bufon, D. Plut, A. Kučan, M. M. Klemenčič in V. Drozg. Černe (1999) izpostavlja gospodarski, tržni vidik identitete kot investicije v 
potrošnjo, prodajanje 'imagea' kraja, tekmovanje pri opredeljevanju kulturnega in simbolnega kapitala. Zupančič (2003) se ukvarja predvsem z narodno identiteto.

Raziskava na Gorenjskem (Klemenčič, M. M., 1995; 1997) je pokazala, da je lokalna identiteta odličen kazalec (ne)stabilnosti družbenogeografskih razmer oziroma stopnje (ne)uravnoteženosti med lokalno družbo in njenim naravnim okoljem. Bufon (1999) navezuje identiteto na teritorialnost; 'anonimnemu' območju dajejo elementi in vidiki poseben značaj, opredeljujejo teritorialno enoto, tej pa v njej delujoče dominantne družbene skupine določijo ime, obseg in meje. A. Kučan (1998) navezuje regionalno identiteto na simbolne elemente pokrajine. Za razliko od drugih regionalizacij Plut (1999) v svoji regionalizaciji prvič izpostavlja identitetni vidik, Drozg (2004) pa povezuje prostorske identitete $\mathrm{z}$ družbenim delovanjem.

Obsežna raziskava Spoznavni zemljevid Slovenije (2002) je prikazala določene prvine regionalnih identitet (Klemenčič, M. M., 2002a). Avtorji se v raziskavah ukvarjajo predvsem z regionalno identiteto (občutkom regionalne pripadnosti) prebivalcev neke regije kot že obstoječim stanjem, analiz, ki bi preučevale vzroke, pa nismo zasledili. Prav tako se redki sprašujejo o posledicah regionalne identitete.

V Sloveniji je bilo narejenih nekaj raziskav, v katerih avtorji izhajajo iz regionalne pripadnosti prebivalcev posamezne regije. Navajamo nekaj primerov: Pomurje in regionalna identiteta Prekmurja (Klemenčič, M. M, 2002b), Regionalna identiteta mladih v Zasavju (Marot, 2005), Razsežnosti regionalne identitete na primeru Istre in Koroške (Zupančič, 1997).

\section{I.2. Metodologija}

V sklopu doktorske disertacije z naslovom Identitetne regije Slovenije (Kosi, 2012), iz katere izhaja ta prispevek, smo ugotavljali tudi regionalno pripadnost. Pri delu smo uporabili hevristično metodo in z njo opredelili ter spoznali razsežnost temeljnih pojmov, na katerih sloni raziskava o regionalni identiteti v Sloveniji. Z metodo intervjuja smo pridobili informacije o tem, kako se prebivalci regionalno opredeljujejo in na podlagi katerih dejavnikov sloni njihovo prepričanje. S kartografsko metodo smo prikazali območja regionalne pripadnosti.

Da bi ugotovili regionalno pripadnost, smo naredili intervjuje na terenu. Intervjuji (pogovori) so bili narejeni od leta 2006 do 2009. Intervjuvali smo 440 naključno izbranih oseb iz najrazličnejših delov Slovenije. Na terenu smo po celotnem območju Slovenije intervjuvali naključne mimoidoče, ki so bili pripravljeni sodelovati, precej intervjujev smo v različnih slovenskih krajih pridobili tudi na seminarjih in delavnicah o zdravem načinu življenja.

V intervjujih nas je zanimal odnos prebivalcev do območja bivanja, kako ga poznajo, čutijo, kako se z njim identificirajo. Z intervjujem smo želeli pridobiti informacije o tem, kako prebivalci živijo, s katerimi institucijami so povezani, kako čutijo svojo regijo, kako vrednotijo njene kvalitete in se hkrati zavedajo posebnosti in težav. To smo poskušali narediti s čim bolj neformalnim pogovorom. Intervju je bil delno strukturiran, kar pomeni, da je bilo nekaj vprašanj naprej zastavljenih, želja pa je bila, da vprašani čim bolj 
svobodno izrazijo svoj odnos do regije, v kateri živijo. Intervjuvali smo na območju cele Slovenije in tudi v nekaterih mestih (Ljubljana, Kranj, Maribor), kamor so prišli posamezniki iz drugih delov Slovenije.

\section{2. ŠIRŠA TEORETIČNA PODSTAT REGIONALNIH IDENTITET}

Teoretično podstat prispevka predstavljajo naslednja širša družbenogeografska teoretična izhodišča:

Izhodišče 1: prvi vsebinski obrat v družbeni geografiji - od spoznavanja družbe k spoznavanju socialnih skupin in posameznika (individualizacija družbenogeografskega preučevanja).

Do sedemdesetih let prejšnjega stoletja se je družbena geografija osredotočala na preučevanje prebivalstva kot celote. Prebivalstvo je obravnavala po posameznih kategorijah (stari, mladi, aktivni, vzdrževani), težišče pa je bilo na celoti. V osemdesetih letih se je izkazalo, da je prebivalstvo preveč diferencirano za tak način preučevanja. Zato je bil uveden termin 'socialna skupina'.

Socialna skupina pomeni združbo ljudi z enakimi socioekonomskimi značilnostmi, ki na enak način delujejo v prostoru (Drozg, 2004). V devetdesetih letih prejšnjega stoletja se je izkazalo, da je tudi socialna skupina preveč heterogena, zato se je težišče preučevanja prestavilo k življenjskim stilom. Takšno drobljenje je predvsem posledica različnih šol in s tem pristopov, oziroma smeri znotraj družbene geografije. Sicer pa so se družbene geografije med seboj precej razlikovale in to prvenstveno zaradi različnih teoretičnih izhodišč.

V geografiji je, kljub njeni holistični zasnovi, prisoten splošni trend drobljenja predmeta preučevanja, tudi sam koncept spoznavanja se je spremenil od spoznavanja splošnih značilnosti k spoznavanju posebnosti. Ena takšnih tematik je prav vprašanje regionalne pripadnosti.

Izhodišče 2: drugi vsebinski obrat v družbeni geografiji - od spoznavanja prostora $\mathrm{k}$ spoznavanju kraja.

Do sredine osemdesetih let prejšnjega stoletja se je geografija omejevala predvsem na fizični prostor in kar je bilo vidno v fizičnem prostoru, je bil predmet preučevanja. Werlen (1993) pravi, če bi geografija še naprej preučevala samo fizični prostor, bi bilo poznavanje prostorskih struktur nepopolno. Naloga geografije naj ne bi bila le preučevanje fizičnega prostora, temveč tudi akterjev, ki prostor ustvarjajo - sooblikujejo. Vse, kar se danes dogaja v družbi, pogosto ni več (direktno) razvidno v prostoru, človekovo delovanje se ne odraža vedno v fizičnem prostoru. Zato je nastala potreba po uporabi termina 'socialni prostor'. To je dinamičen pojav, v katerem posamezniki delujejo in vstopajo v interakcijo drug z drugim, pa tudi prostor, kjer se ljudje pri teh interakcijah srečujejo z najrazličnejšimi organizacijami družbenega in ekonomskega življenja (Kosi, 2012). Sodobna geografija daje velik poudarek prav spoznavanju prostorskih implikacij (posledic) ekonomskega in socialnega življenja. Pri regionalnih identitetah se tudi vedno 
bolj poudarja osebna percepcija prostora, kar je prispevek predvsem anglosaške geografije, izhajajoče iz dediščine behaviorističnih pogledov in vplivov.

Izhodišče 3: zanimajo nas vzvodi, ki ustvarjajo regionalne razlike v sodobnem času.

Prevladujoča gospodarska dejavnost se vedno manj odraža v prostoru (terciarne in kvartarne dejavnosti). Ne moremo pa reči, da človek ni več teritorialno bitje. Še vedno obstaja vez človek - prostor, le da so se oblike povezav spremenile. Postavlja se vprašanje, kakšne so sodobne vezi med prostorom in človekom. Na podlagi večletnih raziskav ugotavljamo, da so lahko regionalne identitete in identitetne regije nekatere izmed oblik odnosa človek - prostor.

Pri preučevanju regionalne identitete poskušamo izhajati iz širših teoretičnih spoznanj, zato upoštevamo sodobne pristope v družbeni geografiji. Sodobno družbeno geografijo zaznamuje nekoliko drugačen koncept spoznavanja: namesto odkrivanja zvez med naravo in družbo, stopajo v ospredje prostorski učinki človekovega delovanja, oziroma učinki, ki so posledica odnosov, v katere stopajo posamezniki z namenom zadovoljevanja svojih potreb. V tem smislu izstopa dvoje raziskovalnih tematik:

Prvo področje so oblike delovanja (odnosov), ki se kažejo v prostoru. V teoriji socialne geografije obstaja šest osnovnih oblik človekovega delovanja oziroma zadovoljevanja potreb: bivanje, delo, oskrba, izobraževanje, rekreacija in komunikacija. Navedene oblike imajo učinke tudi v fizičnem prostoru in skozi nje stopa posameznik v najrazličnejše socialne odnose, ki so tudi prostorsko relevantni. »Zato se med posameznikom in prostorom, kjer posameznik živi in zadovoljuje svoje potrebe, spletejo številne in tesne vezi, zaradi katerih sta skupnost in prostor povezani entiteti.« (Giddens, 1992, str. 218; podobno tudi Weichhart, 1990, str. 36).

V družbeni geografiji so bogato dokumentirani učinki ekonomskega delovanja človeka (dela in oskrbe), podobno tudi učinki bivanja (npr. socialna in prostorska diferenciacija). Manj so poznani celokupni učinki človekovega delovanja na določenem prostoru, ki niso razpoznavni le na področju fizičnega, ekonomskega ali socialnega, temveč segajo še na področje duhovnega (Drozg, 2004). Tovrstne vezi prav gotovo obstajajo, izražajo pa se v pojmih kot so regionalna zavest, občutek regionalne pripadnosti, regionalna identiteta, teritorij, identitetna regija. Na čem temeljijo te vezi, kako se $\mathrm{v}$ prostoru manifestirajo, katere vezi med posameznikom in prostorom so regionalno različne, je zaenkrat še slabo poznana tematika.

Drugo področje se nanaša na manifestacijo (posledice) človekovega delovanja $\mathrm{v}$ prostoru. Po teoriji delovanja človeka (nem. Handlungstheorie, angl. action theory) ima vsaka človekova aktivnost prostorske implikacije (učinke). V prostorski sociologiji in v sodobni družbeni geografiji je razširjeno mnenje, da sta socialno in prostorsko nedeljiva kompleksa (Massey, 2003). Löw (2001) isto spoznanje pojasnjuje z besedami, da so prostorske strukture hkrati tudi socialne strukture. Posledice človekovega delovanja se v pokrajini (prostoru) odražajo na različne načine. V družbeni geografiji so dobro dokumentirane demografske regije, regije dnevnih migrantov, socioekonomska območja. Zelo malo pa vemo o regijah, ki so posledica delovanja družbenih institucij, medijev, organiziranega javnega življenja, regionalne pripadnosti - dejavnosti, ki razkrivajo vezi med prostorom in skupnostjo, kjer ta živi in deluje. 
Tako prva kot druga omenjena raziskovalna problematika sta tesno povezani s pojavom regionalnih identitet. To si razlagamo na sledeči način: prebivalci na nekem območju so med seboj povezani z neštetimi vezmi in skupnimi izkušnjami, ki jih v sodobnem času neprestano producirajo in vzdržujejo vzvodi družbene organizacije: družbene institucije, uprava, gospodarski subjekti, mediji in druge oblike javnega življenja. Zaradi teh vezi se v ljudeh vzbudi občutek regionalne pripadnosti, kar preraste $\mathrm{v}$ regionalno identiteto in lahko kulminira $v$ identitetnih regijah.

\section{REGIONALNA IDENTITETA}

Pojem 'regionalna identiteta' vsebuje pojma 'identiteta' in 'regija'. Identiteta pomeni skladnost, ujemanje, istovetnost. Prostorska identiteta pomeni istovetenje (identificiranje) s prostorom, običajno s prostorom bivanja. Ko govorimo o prostorski identiteti, mislimo na identitete, vezane za prostor na splošno. Obstajajo lahko najrazličnejši prostorski nivoji, od pripadnosti ozkemu bivalnemu okolju do globalnih dimenzij.

Regija označuje območje s specifičnimi naravno- ali družbenogeografskimi značilnostmi, opredeljevanje le-teh pa sodi med osnovne namene geografske vede. Regija je strukturni in večplastni pojem, kar pomeni, da je njena vsebina odvisna od zornega kota gledanja. Vendar je zaradi kompleksnosti in večpomenskosti koncept regije med geografi predmet diskusij in polemik. V sodobnem času se definicija regije glasi: »Regija je srednje veliko območje, ki se po določenih značilnostih razlikuje od sosednjega." (Vrišer, 1978, str. 132). Takšno, na videz jasno in odprto pojmovanje, pa se ob podrobnejši premotritvi izkaže za zelo nedorečeno (Drozg, 2004), saj lahko ugotovimo, da se v definiciji pojavljajo trije ključni poudarki (Drozg, 2004, str. 17):

- velikost območja;

- elementi (značilnosti), ki so predmet razlikovanja in

- zaokroženost območja.

\section{Velikost območja}

Regija je 'srednje veliko območje', torej nekaj med lokalnim in nacionalnim, v času globalizacije tudi planetarnim, oziroma nekaj med najmanjšimi deli zemeljskega površja (ekotopi) in ekohorami. Velikost regije se zmeraj nanaša na kontekst, v katerem jo obravnavamo, ker pa kontekst ni poznan vnaprej, tudi velikost regije ne more biti natančno določena. Dilemo z velikostjo regije geografi velikokrat rešujemo z uvajanjem makro-, mezo- in mikroregij, pri čemer je potrebno regije različnega nivoja definirati z njimi lastnimi elementi, saj gre za nove in samostojne prostorske enote (Drozg, 2004, str. 17).

\section{Elementi, ki določajo regijo}

Regijo določa eden ali več izbranih elementov, zaradi česar je prostorsko zaokroženo območje. Vprašanje je, na podlagi katerih kriterijev je regija zaokroženo območje ter kdo in s kakšnim namenom (interesi) pojmuje regijo kot zaokroženo območje? Drugo vprašanje nakazuje, da so regije konstrukti, artefakti, s katerimi človek pojasnjuje in prikazuje 
razmestitev pojavov v prostoru. Zato je regij iz vsebinskega vidika toliko, kolikor je atributov prostorskih elementov.

\section{Zaokroženost območja}

Regija je prostorsko zaokroženo območje s čvrstim, jasno prepoznavnim jedrom, proti zunanjim mejam pa prehaja v sosednjo regijo. Razmejevanje regij je zato zmeraj iskanje kompromisa med dilemo, »kaj je še regija in kaj ni več«. Dodati je potrebno, da je opredeljevanje mej le redkokdaj povsem nesporno. Posebej težavno je razmejevanje $\mathrm{v}$ primerih, ko imamo opraviti z elementi z majhno prostorsko relevantnostjo. Zaradi pogosto nejasnih meja regije se je pojavil način razmejevanja, ki nosi ime 'fuzzy logic' (Güssefeldt, 1997, str. 1), katerega bistvo so regije, pri katerih se meje prekrivajo. S tem je zmanjšan problem 'na silo' določenih mej, regionalizacija pa je bliže dejanskim razmeram v prostoru (Drozg, 2004).

Tako regija ni več nekaj celostnega, ne zajema več vseh pokrajinotvornih elementov, temveč se nanaša samo na izbrane (Drozg, 2004). V pokrajini se ne pojavlja le ena sama, kompleksna, regija, ampak več regij, od katerih vsaka zamejuje posebne značilnosti pokrajine. Razlog za takšen preobrat je vse manjša 'prostorskost' življenja in vse ohlapnejše vezi med naravnim in družbenim segmentom; povezanost družbenih razmer z naravnimi je danes veliko manjša, kot je bila v času agrarne družbe (Drozg, 2004). S tem se odpira možnost tudi za drugačne poglede na regijo.

Za celovito razumevanje obravnavane tematike je treba na kratko pojasniti pojme 'kraj', 'prostor' in 'teritorij'. Pojem 'kraj' (angl. place), ima pri obravnavi regionalnih identitet posebno mesto. Po Paasiju (1986) je kraj prostorsko-časovni gradnik regije. Kraj vedno nakazuje občutenje, izkušnjo, čeprav izkušnja ni nujno vedno prijetna. Vsebina pojma 'kraj' je kakovostno drugačna od pojmov 'pokrajina' ali 'prostor' (Butz, Eyles, 1997). V splošnem je pojem 'prostor' bolj abstraktna, neosebna kategorija, pojem 'kraj' pa je povezan z osebnim doživljanjem. Ponazorimo si lahko, da je regija stavba, kraji pa so opeke, ki gradijo to stavbo. Kraj lahko pojmujemo tudi kot vsakdanji svet in je človeku najbližja stvarnost, primarna stvarnost, na katero se vedno nanašamo, kot nujno ozadje, horizont vseh razumevanj in početij ljudi - je nam bližje življenjsko območje, od katerega se ne moremo odtrgati, kot se lahko od bolj abstraktnih svetov, npr. sveta politike ali religije (Proshansky, Fabian, Kaminoff, 1983).

$\mathrm{V}$ povezavi z regionalnimi identitetami se pogosto omenjata pojma 'teritorij' in 'teritorialnost'. Teritorij je območje, ki si ga lasti določena družbena skupnost. Teritorialnost označuje posest, prisvojitev določenega prostora in nadzor nad njim, to pa je predpogoj za nastanek in ohranjanje regionalnih identitet.

Regionalna identiteta je pojav, ki povezuje objektivne (narava, gospodarstvo) in subjektivne (posamične in kolektivne) značilnosti. Za celovitejši vpogled v vsebino regionalne identitete omenja Keating (1998, str. 86) tri pomembne elemente:

- spoznavnega: ljudje se morajo zavedati regije in njenih meja, da se ločijo od drugih regij;

- čustvenega: ljudje čutijo regijo, ki jim zagotavlja okvir za skupno identiteto;

- instrumentalnega: stanje, ko je regija uporabljena kot osnova za mobilizacijo in kolektivno akcijo pri uresničevanju družbenih, gospodarskih ali političnih ciljev. 
Podobne elemente izpostavlja tudi Paasi (1986), ki meni, da pri oblikovanju regionalne identitete potekajo istočasno trije procesi:

- teritorialnost: pojavljanje meje pri različnih družbenih dejavnostih, ki ločijo regijo in regionalno identiteto od sosednjih;

- simbolnost: ime regije in številni drugi simboli, ki imajo funkcijo vzpostavitve različnosti od drugih;

- institucionalnost: ustanove, ki vzdržujejo simbolne oblike in hkrati razlikujejo regije med seboj.

Regionalno identiteto sestavljajo na zunaj prepoznavni ali objektivni elementi in subjektivni elementi, to je zavest pripadnosti. Zato lahko tudi pojav regionalne identitete obravnavamo z objektivnega ali subjektivnega vidika. Dvojni vidik izvira iz dvojne strukture družbe: na eni strani imamo organizacije in sisteme družbenega življenja, ki ustvarjajo specifičen ustroj družbe, na drugi pa skupnost in posameznika. Iz objektivnega vidika lahko preučujemo regionalne identitete skozi različne oblike družbenega delovanja, ki pogosto poteka skozi družbene organizacije (institucije) in te vplivajo na regionalno zavest. Iz subjektivnega pa pristopamo z vidika skupnosti (družbenih skupin), ki temeljijo na vrednotah, normah, simbolih, tradiciji in pripadnosti ter predstavljajo sestavine regionalne zavesti.

Slika 2: Objektivni in subjektivni vidik nastanka regionalnih identitet

Figure 2: Objective and subjective origin of regional identities

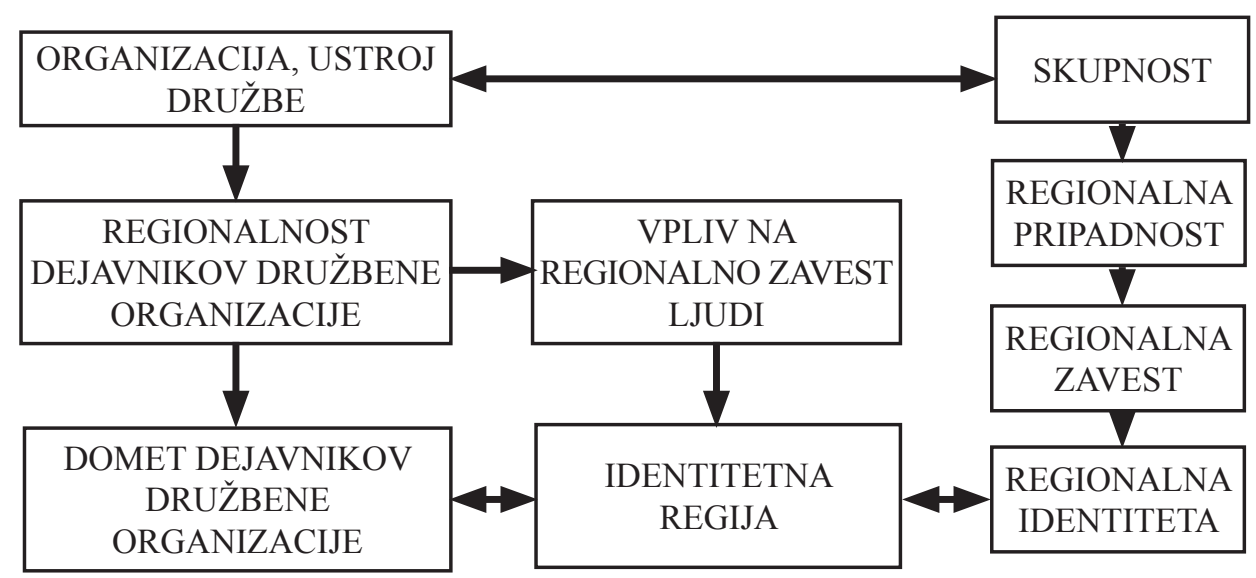

Pri objektivnem pristopu izhajamo iz organizacije in ustroja družbe. Med posameznikom, skupnostjo in prostorom, kjer človek živi in zadovoljuje svoje potrebe, se spletejo številne in tesne vezi, zaradi katerih sta skupnost in prostor medsebojno povezani entiteti. Vsaka skupnost ima specifično organizacijo življenja, deluje po določenih principih skozi široko paleto družbenih organizacij. Pri razumevanju objektivnega pristopa je bistvenega pomena delovanje človeka, ki je po Webru osnovni gradnik družbe; pravi, da je »človekovo 
delovanje atom socialno-kulturnega univerzuma.« (Werlen, 2000). Za socialno delovanje pravi Werlen (2000), da je to tisto delovanje, ki je namensko in ciljno usmerjeno v različne socialne interakcije, ki imajo za posledico zadovoljitev različnih potreb. Meni, da se družbeno delovanje odvija v glavnem skozi gospodarstvo, institucije in medije. Te dejavnosti tvorijo t. i. akcijske prostore, na katere se vežejo regionalne identitete in s tem identitetne regije.

Werlen (2000) meni, da je vsakdanje delovanje človeka za zadovoljevanje določenih potreb bistveno pri procesu prostorskega identificiranja, saj se z zadovoljevanjem potreb skozi družbene organizacije v določenem prostoru vzpostavi povezava, navezava, identiteta s tem prostorom. Podobno razmišlja o povezavi družbenega delovanja, prostora in identitet tudi Kymlicka (1995, str. 17-19). Prostorske identitete povezuje s t. i. societalno kulturo (societal culture), ki omogoča posameznim članom, da najdejo smiselni način bivanja v družbi skozi vrsto dejavnosti na gospodarskem, socialnem, vzgojnoizobraževalnem, verskem in športnem področju, in to tako v zasebni kot javni sferi. Pravi, da se lahko taka kultura razvije le na teritorialno omejenem prostoru. Kymlicka nadaljuje, da se lahko vpliv na družbeno življenje in s tem na prostorske identitete vzpostavi preko družbenih organizacij, kot so šole, mediji, gospodarstvo, uprava. Trdi, da organizacije družbenega življenja, ki omogočajo njenim pripadnikom udeležbo v javnem življenju, povečujejo občutek pripadnosti neki skupnosti in prostoru.

Pri subjektivni perspektivi preučevanja regionalnih identitet izhajamo iz pojma 'skupnost'. Seštevek posameznikov je skupina, ta lahko postane skupnost, če posamezniki v njej prevzamejo vzorce kolektivnega obnašanja in medsebojne interakcije. V skupnosti so ljudje nujno povezani in na določene načine soodvisni. Kolektivna identiteta se lahko oblikuje samo znotraj skupnosti, ki ima določene skupne - podobne značilnosti in jih je kot take mogoče opaziti. Vsaka skupnost ima svojo regionalno zavest, ki se oblikuje iz regionalne pripadnosti in se kaže v regionalni identiteti. Socialni geografi menijo (mdr. Werlen, Weichhart, Paasi), da skupnosti delujejo v regijah na različne načine. Različne oblike delovanja v regiji pomenijo različne oblike doživljanja, dojemanja in vezanosti na lastno regijo, iz tega pa sledijo različne regionalne identitete.

Tudi subjektivni pristop, ki izhaja iz skupinske zavesti, doživljanj in prepričanj, je povezan z družbenim delovanjem. Giddens (1992) pravi, da človekovo delovanje v prostoru temelji na treh stopnjah zavesti in da so vse tri stopnje povezane s prostorskimi identitetami:

- podzavest: delovanje, ki prihaja iz nezavednih motivov, želja in potreb;

- praktična zavest: znanje s katerim razpolagamo in skozi to znanje delujemo, ne da bi razmišljali o njem;

- diskurzivna zavest: znanje, ki ga pri svojem delovanju zavestno uporabljamo ter spreminjamo.

Pri vzrokih za nastanek regionalne identitete razmišljamo o vzvodih, mehanizmih in dejavnikih, ki jo povzročajo in ohranjajo. Domnevamo, da lahko s preučevanjem regionalnosti posameznih dejavnikov regionalnih identitet in njihovega prostorskega dometa, potrdimo njihov vpliv na regionalno identiteto.

Iz različnih virov v literaturi (npr. Paasi, 1986; Weichhart, 1990; Werlen, 2000) lahko ugotovimo, da so v sodobnem času družbene institucije, mediji, uprava, gospodarski 
subjekti in množični šport ključni dejavniki oblikovanja in ohranjanja regionalnih identitet. Seveda obstajajo tudi tradicionalni dejavniki, pokrajina, zgodovinski razvoj, kultura, jezik in narečje, vendar se $\mathrm{v}$ raziskavi osredotočamo na sodobne. Njihov vpliv si predstavljamo na sledeč način: omenjeni dejavniki delujejo na določenem območju, vežejo nase ljudi s tega območja in zaradi tega nastajajo prostorske enote. $Z$ zadovoljevanjem potreb na določenem območju, tudi skozi omenjene dejavnike, se lahko vzpostavi identiteta s tem območjem. V vzporedni raziskavi smo preučili vpliv omenjenih dejavnikov na pojav regionalnih identitet in na osnovi njihovega dometa določili identitetne regije v Sloveniji (Kosi, 2012).

Slika 3: Koncept raziskave regionalne identitete

Figure 3: Concept of researching regional identity

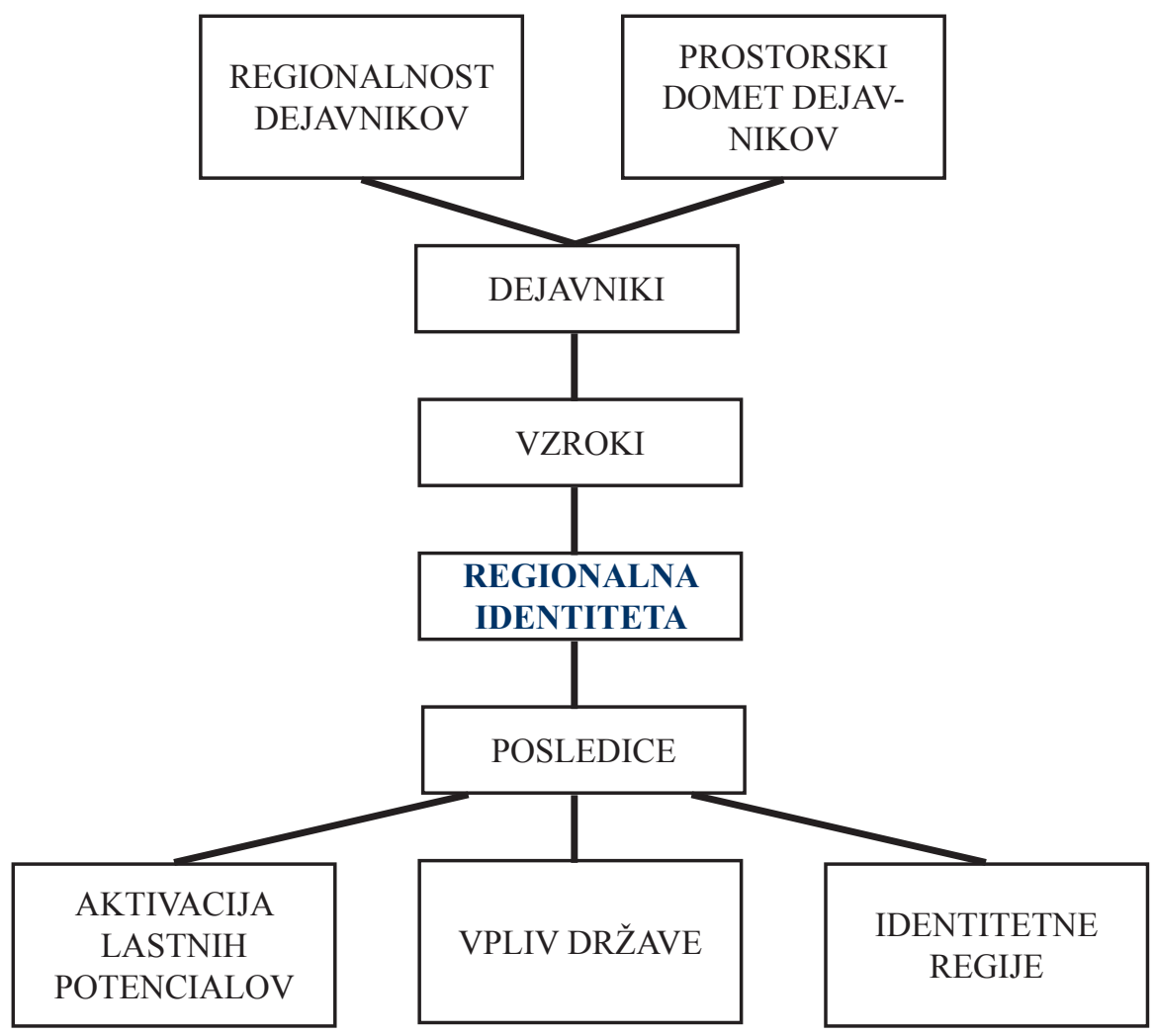

V sklopu doktorske disertacije z naslovom Identitetne regije Slovenije smo preučevali različne vidike regionalnih identitet (Kosi, 2012). Regionalna identiteta ni teoretični konstrukt, temveč praktična realnost s konkretnimi posledicami v določeni regiji. Pojem vsebuje v sebi velik emotivni naboj/potencial, ki se lahko manifestira na raznih področjih življenja (socialno-političnem, ekonomskem, prostorskem) in ima pomembne posledice za preobrazbo 
prostorskih struktur. Regionalna identiteta se kaže skozi dojemanje in vrednotenje prostora, $\mathrm{v}$ katerem živijo prebivalci, in se pogosto kaže v mnogih pobudah, akcijah in tudi nestrinjanjih, protestih; skratka, regionalna identiteta spodbuja mobilizacijo prebivalstva.

Občutek pripadnosti regiji pa ni le čustven odnos, ampak zelo konkreten odnos ljudi do okolja bivanja in se kaže tudi prek soudeležbe pri urejanju skupnih zadev. Ob določenih 'neugodnih pobudah' s strani države se vzpostavijo iniciative, ki želijo preprečiti določena dogajanja v 'domačem' okolju, s katerimi se prebivalci ne strinjajo.

Tako regionalna identiteta vpliva na aktiviranje lastnih potencialov prebivalcev in pogosto sproži tudi posege države v prostor, npr. urejanje infrastrukture in tudi določevanje upravnih delitev, ki so lahko ob upoštevanju pripadnosti regiji manj konfliktne. Predvsem skozi prostorski domet dejavnikov kot enega od posledic pojava regionalne identitete lahko prepoznamo tudi identitetne regije.

Regionalna identiteta torej vpliva na razvoj in posledično deluje kot pomemben dejavnik preoblikovanja pokrajine. Predstavlja potencialni stimulator različnih dejavnosti, ki lahko prinesejo nov razvoj in posledično tudi spremembe v prostorski strukturi. Na ta potencial lahko gledamo iz dveh zornih kotov: $\mathrm{z}$ vidika prebivalstva določene regije in $\mathrm{z}$ vidika države. $Z$ vidika vsakdanjega življenja ljudi neke regije vsebuje regionalna identiteta močan impulz mobilizacijske moči, zmogljivost, ki jo spodbuja obstoj kolektivnega zavedanja povezane skupnosti. Občutek MI ali NAS da ljudem posebno energijo, ki lahko izhaja tudi iz dokazovanja, želje po prepoznavnosti.

Prebuja in izgrajuje se tudi zavest o bogatih usedlinah iz preteklosti, zavedanje regionalnih posebnosti, ki se ne smejo pozabiti in izgubiti. Takšno zavedanje ima lahko posledice na mnogih področjih življenja (kulturno-umetniško delovanje, ohranjanje in obnavljanje kulturne dediščine, vlaganje $\mathrm{v}$ regionalne posebnosti). $\mathrm{Z}$ dvigom zavedanja o pomenu športnega udejstvovanja, povezanega z zdravim načinom življenja, se izgrajuje športna in rekreativna infrastruktura (dvorane, igrišča, tekaške, kolesarske proge, sprehajalne poti, bazeni, parki, igrala na otroških igriščih). Podobno velja tudi za zavedanja o vrednosti zgodovinske in kulturne dediščine (obnova kozolcev, mlinov, arhitekturnih elementov, solin, muzejev, sakralnih objektov). Takšno zavedanje ima pogosto za posledico tudi posege v fizično okolje.

Drugi vidik regionalne identitete je povezan z delovanjem države. Ko se začne 'država' s svojimi institucijami zavedati regionalne identitete, začne v njo vlagati, jo razvijati in utrjevati. Nastajajo nove ustanove (npr. agencije za regionalni razvoj), poskušajo se reševati neugodne gospodarske razmere, tudi z iskanjem različnih razvojnih, gospodarskih niš, povezanih z regionalnimi možnostmi.

\section{IDENTITETNE REGIJE}

Ena od posledic regionalne identitete je tudi obstoj identitetnih regij. Če obstajajo dejavniki, ki delujejo regionalno identitetno, imajo tudi nek prostorski obseg delovanja. In znotraj nekega prostora, ki ga zamejujejo vplivi dejavnikov na prostorsko zavest ljudi, živijo ljudje $\mathrm{z}$ enako regionalno pripadnostjo. Ta lahko na nekem območju predstavlja okvir za definiranje nove oblike regije, postavljene na osnovi regionalne identitete prebivalcev - identitetne regije (Kosi, 2012). 
Obstoj identitetne regije si lahko razlagamo na sledeči način: prebivalci na nekem območju so med seboj povezani z neštetimi vezmi in skupnimi izkušnjami, ki jih neprestano producirajo in vzdržujejo družbene institucije, gospodarski subjekti, mediji in druge oblike javnega življenja. Zaradi teh vezi se v ljudeh vzbudi občutek regionalne pripadnosti, kar preraste $\mathrm{v}$ regionalno identiteto. Identitetna regija je torej območje, ki ga povezuje podobno stanje duha ter pripadnost istim družbenim institucijam, upravnim delitvam, gospodarskim subjektom, množičnim medijem, športnim klubom, posledica tega pa je občutek regionalne pripadnosti oziroma identifikacija s tem istim območjem (Kosi, 2012).

In v čem se pojem 'identitetna regija' razlikuje od pojma 'regija'? Pojem 'identitetna regija' predstavlja eno izmed vrst regij. Kot obstajajo na primer ekonomske regije, ki nastanejo zaradi ekonomskih dejavnikov, obstajajo tudi identitetne regije, nastale kot posledica regionalne identitete prebivalcev. Pri gospodarskih regijah je gospodarska dejavnost tista, ki predstavlja mehanizem povezovanja znotraj nekega območja. Podobno obstajajo tudi identitetne regije, kjer je regionalna identiteta prebivalcev tisti povezovalni element, ki določa identitetne regije.

Kot je mogoče različne regije opredeliti na podlagi različnih kazalcev, se lahko tudi identitetne regije opredeli na osnovi regionalne identitete prebivalcev, oziroma dejavnikov, ki jo ustvarjajo in ohranjajo.

\section{REZULTATI RAZISKAVE O REGIONALNI PRIPADNOSTI PREBIVALCEV SLOVENIJE}

V sklopu doktorske disertacije z naslovom Identitetne regije Slovenije (Kosi, 2012) smo ugotavljali tudi regionalno pripadnost. Regionalna pripadnost pomeni pripadnost prebivalcev svoji regiji. Predstavlja osnovo regionalni zavesti in regionalni identiteti. Socialni geografi so prvi začeli opozarjati na obstoj regionalne identitete in pojav regij, ki so umeščeni v zavesti njihovih prebivalcev (insiders) ali prebivalcev drugih regij (outsiders). Regionalna pripadnost nastane tam, kjer so deli narodnega ozemlja geografsko in socialno zadostno povezani, da se vzpostavi zavest lastne edinstvenosti in da so ponosni na lastne običaje in ideale ter da imajo občutek ločenosti od ostalih območij.

Za preučitev regionalne pripadnosti smo uporabili metodo intervjuja na terenu. Intervjuji so bili opravljeni v letih od 2006 do 2009. Avtor prispevka je sam intervjuval 440 ljudi na območju celotne Slovenije. V vzorec smo zajeli naključno izbrane osebe in pri tem posebej pazili, da so bili vključeni anketiranci iz celotne Slovenije. Avtor ni vnaprej določil minimalnih ali maksimalnih kvot za posamezno območje, saj bi s tem že vnaprej določil posamezne regije. Poudarek je bil na tem, da čim bolje pokrijemo celotno območje Slovenije. Po našem mnenju sta velikost in razporeditev vzorca ustrezna, saj smo v raziskavi iskali tipične značilnosti in ne posebnosti.

Pri intervjuvancih je bila spolna struktura vprašanih enakomerna, 48 \% (211) moških in $52 \%$ (229) žensk. Starostna struktura vprašanih kaže na prevladujoč delež starih od 36 do 50 let $(36 \% ; 158)$ in 26-35 let $(27 \%$; 118), v starostni kategoriji 18-25 let je bilo $18 \%$ intervjujancev (80) in nad 51 let $19 \%$ (84). Izobrazbena struktura vprašanih kaže na nadpovprečni delež izobraženih v vzorcu, predvsem tistih s končano višjo in visoko izobrazbo 
(45 \%; 198 ljudi), z osnovno šolo je bilo 12 \% (53), s srednjo šolo 36 \% (158) in z magisterijem ali doktoratom 7 \% (31). Delež visoko izobraženih res odstopa od dejanske izobrazbene strukture, a se je izkazalo, da se ljudje podobno regionalno umeščajo in identificirajo ne glede na izobrazbo. V kar nekaj primerih je bilo med intervjuvanjem opaziti, da se ljudje z nižjo izobrazbo še nekoliko bolj emotivno odzivajo na tovrstna vprašanja.

$\mathrm{V}$ intervjuju nas je zanimal odnos prebivalcev do območja bivanja, kako ga poznajo, kako ga čutijo, kako se z njim identificirajo. Z intervjujem smo želeli pridobiti informacije o tem, kako prebivalci živijo, s katerimi ustanovami so povezani, kako čutijo svojo regijo, kako vrednotijo njene kvalitete in se hkrati zavedajo posebnosti in težav. To smo poskušali narediti s čim bolj neformalnim pogovorom. Intervju je bil delno strukturiran, kar pomeni, da je bilo nekaj vprašanj zastavljenih vnaprej, želeli pa smo, da vprašani čim bolj svobodno izrazijo svoj odnos do regije, v kateri živijo.

Vprašanim smo postavili sledeča vprašanja:

1. Kraj bivanja

2. Starost

3. Stopnja izobrazbe

4. Kako se prostorsko opredeljujete?

5. Kako doživljate regionalno identiteto - pripadnost?

6. Kje delate, se oskrbujete?

7. Kaj je po vašem mnenju središče regije, v kateri živite?

8. Kateri časopis berete najpogosteje?

9. Kateri radijski program poslušate najpogosteje?

10. Kateri televizijski program gledate najpogosteje?

11. Katera banka je najbolj prisotna na vašem območju?

12. Kateri športni klubi v regiji so najpopularnejši?

13. Vprašanja o poznavanju kulturne infrastrukture (muzeji, knjižnice, gledališča)

14. Lahko približno določite meje svoje regije?

Pri vprašanih smo iskali ključne motive, ki nakazujejo regionalno pripadnost. Zanimalo nas je, zakaj čutijo svoje okolje na takšen način. Zanimalo nas je tudi, kakšen je njihov odnos do okolja: bolj tehničen, utilitaren, praktičen z vidika zadovoljevanja potreb ali prevladuje čustven odnos, navezanost, vpetost v okolje na emocionalni bazi. Zaznali smo preplet, povezavo med različnimi vrstami odnosov, da se oba vidika (praktični in emocionalni) dopolnjujeta in 'hranita' drug drugega. Postavljali smo jim tudi vprašanja o tem, kje običajno uresničujejo svoje potrebe po različnih storitvah - od vsakodnevnih (služba, vsakodnevna oskrba, šolanje, rekreacija) do tistih, ki pridejo v poštev le ob razmeroma redkih priložnostih (bolnišnica, gledališče). Spraševali smo po najpogosteje obiskovanem oskrbnem središču, pa tudi po drugem najpomembnejšem središču. Tako je bilo mogoče dobiti predstavo tudi o vplivu manj pomembnega središča, ki je seveda drugotnega pomena, a vendarle prisotno.

Intervjuvance smo spraševali tudi o obiskovanju športnih in kulturnih prireditev. Večina jih spremlja vsaj preko medijev, mnogi se jih tudi udeležujejo. Na podlagi odgovorov lahko ugotovimo, da se vprašani zavedajo pomena regionalne kulture in regionalnega športa v smislu regionalne pripadnosti, saj vsi brez izjeme navijajo ali vsaj simpatizirajo 
z regionalnimi športnimi klubi in skozi njih tudi čutijo regionalno pripadnost. Veliko jim pomenijo tudi regionalne kulturne prireditve.

Odgovori so pokazali, da lahko v Sloveniji prepoznamo 12 identitetnih regij, s katerimi se ljudje najpogosteje identificirajo: Prekmursko, Mariborsko-štajersko, Koroško, Celjskoštajersko, Zasavsko, Posavsko, Dolenjsko, Ljubljansko, Gorenjsko, Notranjsko, Goriško in Primorsko regijo. Nekaj težav smo imeli s poimenovanjem Mariborsko-štajerske in Celjsko-štajerske identitetne regije. Razlog za takšno poimenovanje je v tem, da so intervjuvanci izjavljali, da sta oba centra sicer na Štajerskem, vendar z izrazito individualno identiteto. Menili so, da Celje nima praktično nič skupnega z Mariborom in Maribor nič s Celjem. Pa vendar obe regiji tradicionalno pripadata neki širši prostorski enoti, zgodovinski regiji - oboji so po lastnem prepričanju Štajerci. S takšnim poimenovanjem smo poskušali samo najti nekakšno kompromisno rešitev. Vsaka od 12 identitetnih regij ima svoje središče - nekatere tudi več.

Vprašani so v veliki večini točno vedeli, kateri regiji pripadajo, kaj je njihova 'matična' regija, skoraj enoznačni so bili tudi odgovori glede središča regije. Ponekod je občutek regionalne pripadnosti najmočnejši v središčih regij, proti mejam s sosednjimi regijami slabi (Ljubljanska regija) in se preliva $\mathrm{z}$ drugimi. $\mathrm{V}$ določenih primerih pa je regionalna identiteta ravno na robnih območjih najizrazitejša (vzhodni del Mariborsko-štajerske regije (Prlekija) nasproti Prekmurski regiji). Povzamemo lahko torej, da se prebivalci jasno regionalno identificirajo, v zavesti ljudi so jasno zasidrana tudi središča regij, kar je posledica dejstva, da ljudje uporabljajo storitve, ki so skoncentrirane v posameznem središču.

Slika 4: Regionalna pripadnost prebivalcev

Figure 4: Regional belonging of the people

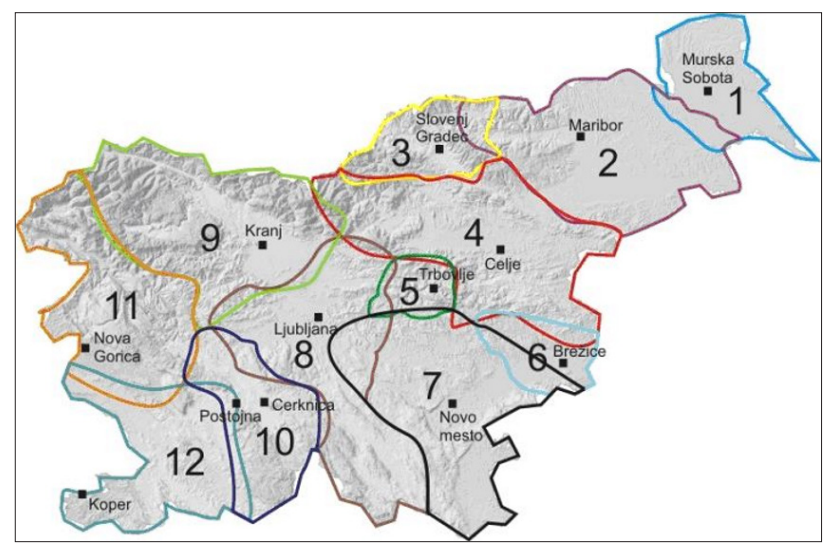

Legenda/Legend

(identitetna regija - središče regije): 1 Prekmurska regija (Murska Sobota); 2 Mariborskoštajerska regija (Maribor); 3 Koroška regija (Slovenj Gradec); 4 Celjsko-štajerska regija (Celje); 5 Zasavska regija (Trbovlje); 6 Posavska regija (Brežice); 7 Dolenjska regija (Novo mesto); 8 Ljubljanska regija (Ljubljana); 9 Gorenjska regija (Kranj); 10 Notranjska regija (Cerknica, Logatec, Postojna); 11 Goriška regija (Nova Gorica); 12 Primorska regija (Koper) 


\section{SKLEP}

Pri preučevanju regionalne identitete poskušamo izhajati iz širših teoretičnih spoznanj, saj sodobno družbeno geografijo zaznamuje nekoliko drugačen koncept spoznavanja: namesto odkrivanja zvez med naravo in družbo stopajo v ospredje prostorski učinki človekovega delovanja, oziroma učinki, ki so posledica odnosov, v katere stopajo posamezniki z namenom zadovoljevanja svojih potreb. Med posameznikom in prostorom, kjer posameznik živi in zadovoljuje svoje potrebe, se namreč spletejo številne in tesne vezi, zaradi katerih sta skupnost in prostor povezana.

V družbeni geografiji so bogato dokumentirani učinki ekonomskega delovanja človeka (npr. dela in oskrbovanja), podobno tudi učinki bivanja (npr. socialna in prostorska diferenciacija). Manj so poznani celokupni učinki človekovega delovanja na določenem prostoru, ki niso razpoznavni le na področju fizičnega, ekonomskega ali socialnega, temveč segajo tudi na področje duhovnega življenja.

Posledice človekovega delovanja se na različne načine kažejo v prostoru. V družbeni geografiji so dobro raziskane demografske regije, regije dnevnih migrantov, socioekonomska območja. Zelo malo pa vemo o regijah, ki so posledica delovanja družbenih institucij, medijev, organiziranega javnega življenja, regionalne pripadnosti - dejavnosti, ki razkrivajo vezi med prostorom in skupnostjo, kjer ta živi in deluje.

Tovrstne vezi prav gotovo obstajajo, kažejo pa se v pojmih kot so regionalna zavest, občutek regionalne pripadnosti, regionalna identiteta, teritorij, identitetna regija. Na čem temeljijo te vezi, kako se v prostoru kažejo, katere vezi med posameznikom in prostorom se razlikujejo po regijah, je zaenkrat še slabo poznana tematika.

Regionalna identiteta je pojav, ki povezuje objektivne (narava, gospodarstvo) in subjektivne (posamične in kolektivne predstave) značilnosti. Vsebuje tri pomembne elemente: spoznavnega, čustvenega in instrumentalnega.

Regionalno identiteto sestavljajo zunanji (prepoznavni ali objektivni) in notranji (subjektivni) elementi, to je zavest pripadnosti. Zato lahko tudi pojav regionalne identitete obravnavamo z objektivnega in subjektivnega vidika. Z objektivnega vidika lahko regionalne identitete preučujemo skozi različne oblike družbenega delovanja, ki pogosto poteka prek različnih družbenih organizacij (institucij), ki vplivajo na regionalno zavest. S subjektivnega vidika pa pristopamo k preučevanju z vidika skupnosti (družbenih skupin), ki temeljijo na vrednotah, normah, simbolih, tradiciji in pripadnosti ter predstavljajo sestavine regionalne zavesti.

Dvojni vidik izvira iz dvojne strukture družbe: na eni strani imamo organizacije in sisteme družbenega življenja, ki ustvarjajo specifičen ustroj družbe, na drugi pa skupnost in posameznika.

Iz različnih virov v literaturi in iz rezultatov intervjujanja lahko ugotovimo, da so v sodobnem času družbene institucije, mediji, uprava, gospodarski subjekti in množični športi ključni dejavniki formiranja in ohranjanja regionalnih identitet; seveda poleg njih obstajajo tudi tradicionalni dejavniki, kot so (po)krajina, zgodovinski razvoj, kultura, jezik in narečje.

Regionalna identiteta ni samo teoretični konstrukt, temveč realen pojav s posledicami na mnogih področjih človekovega življenja. To smo nesporno dokazali z analizo opravljenih 
intervjujev, ki kažejo, da občutek pripadnosti ni le čustven odnos, ampak zelo konkreten odnos ljudi do okolja bivanja in se kaže tudi v soudeležbi pri urejanju skupnih zadev. Zaradi tega se ob določenih 'neugodnih pobudah' s strani države vzpostavijo iniciative, ki želijo preprečiti določena dogajanja v 'domačem' okolju, s katerimi se prebivalci ne strinjajo.

V prispevku smo poskušali dokazati, da regionalna identiteta vpliva na aktiviranje lastnih potencialov prebivalcev in pogosto inicira tudi posege države $\mathrm{v}$ prostor, skozi urejanje infrastrukture in pri določevanju upravnih delitev, ki so lahko ob upoštevanju pripadnosti manj konfliktne.

\section{Viri in literatura}

Bufon, M., 1999. Problematika teritorialnosti v politični in kulturni geografiji. Geografski vestnik, 71, str. 91-103.

Butz, D., Eyles, J., 1997. Reconceptualizing senses of place: social relations, ideology and ecology. Geografiska Annaler, Series B (Human geography), 79, 1, str. 78-98.

Černe, A., 1999. Prostorska identiteta - koncept različnosti. Anthropos, 31, 4-6, str. 296-300.

Drozg, V., 2004. Regija - kontekst ali koncept spoznavanja pokrajine. V: Drozg, V. (ur.). Teorija in praksa regionalizacije Slovenije. Maribor, Pedagoška fakulteta, str. 16-24.

Giddens, A., 1992. Die Konstitution der Gesellschaft. Grundzüge einer Theorie der Strukturbildung. Frankfurt, Campus Verlag, 460 str.

Güssefeldt, J., 1997. Grundsätzliche Überlegungen zu Regionalisierungsmodellen. Geographische Zeitschrift, 85, 1, str. 1-19.

Keating, M., 1998. The new regionalism in Western Europe: territorial restructuring and political change. Northampton (Mass.), E. Elgar, 242 str.

Klemenčič, M. M., 1995. Krajevna identiteta na primeru Srednje in Zgornje Gorenjske. Geografska problematika slovenskega alpskega sveta in slovenskih mest (Dela 11), str. 47-57.

Klemenčič, M. M., 1997. A case study of regional identity problems in Slovenia. V: Wolf, K., Tharun, E. (ur.). Einzelhandelsentwicklung: zielorientierte regionale Geographie. Frankfurt am Main, Institut für Kulturgeographie, Stadt- und Regionalforschung der J. W. Goethe-Universität, str. 87-96.

Klemenčič, M. M., 2002a. Miselna slika pokrajin. V: Polič, M., Repovš, G. (ur.). Spoznavni zemljevid Slovenije. Ljubljana, Znanstveni inštitut Filozofske fakultete, str. $161-180$.

Klemenčič, M. M., 2002b. Pomurje in regionalna identiteta Prekmurja. V.: Kikec, T. (ur.). Pomurje: trajnostni regionalni razvoj ob reki Muri. Zbornik 20. zborovanja slovenskih geografov, Ljutomer - Murska Sobota, 26.-28. marec 2009, str. 8-15.

Kosi, D., 2012. Identitetne regije Slovenije. Doktorsko delo. Maribor, Filozofska fakulteta, Oddelek za geografijo, 203 str.

Kučan, A., 1998. Krajina kot nacionalni simbol. Ljubljana, Znanstveno in publicistično središče, 224 str.

Kymlicka, W., 1995. Multicultural citizenship: a liberal theory of minority rights. Oxford, Clarendon Press, 280 str.

Löw, M., 2001. Raumsoziologie. Frankfurt am Main, Suhrkamp, 189 str. 
Marot, M., 2005. Regionalna identiteta mladih v Zasavju. Geografski vestnik, 77, 1, str. 37-48.

Massey, D., 2003. Spaces of politics - Raum und Politik. V: Gebhardt, H., Reuber, P., Wolkersdorfer, G. (ur.). Kulturgeographie. Aktuelle Ansätze und Entwicklungen. Berlin, str. 31-46.

Paasi, A., 1986. The institutionalization of regions: a theoretical framework for understanding the emergence of regions and the constitution of regional identity. Fennia, 164, 1, str. 105-146.

Plut, D., 1999. Regionalizacija Slovenije po sonaravnih kriterijih. Geografski vestnik, 71, str. 9-25.

Proshansky, H., M., Fabian, A. K., Kaminoff, R., 1983. Place-identity: physical world socialization of the self. Journal of environmental psychology, 3, 1, str. 57-83.

Spoznavni zemljevid Slovenije. 2002. Polič, M., Repovš, G. (ur.). Ljubljana, Znanstveni inštitut Filozofske fakultete, 381 str.

Vrišer, I., 1978. Regionalno planiranje. Ljubljana, Mladinska knjiga, 356 str.

Weichhart, P., 1990. Raumbezogene Identität. Bausteine zu einer Theorie räumlich-sozialer Kognition und Identifikation.Stuttgart, Steiner Verlag, 118 str.

Werlen, B., 1993. Society, action and space: an alternative human geography. London, New York, Routledge, 249 str.

Werlen, B., 2000. Sozialgeographie: eine Einführung. Stuttgart, UTB, 400 str.

Zupančič, J., 1997. Razsežnosti regionalne identitete na primeru Istre in Koroške. Annales, Series historia et sociologia, 7, 10, str. 307-316.

Zupančič, J., 2003. Ključni problemi ohranjanja in razvoja narodne identitete. V: Slovenija in nadaljnji razvoj Evropske unije. CRP - zaključno poročilo. Inštitut za narodnostna vprašanja Ljubljana in Znanstvenoraziskovalno središče Koper, str. 40-64.

\section{REGIONAL IDENTITY IN SLOVENIA}

\section{Summary}

By researching the regional identity, we tried to come out of wider theoretical comprehension. Social geography is denoted with a different concept of cognition; instead of discovering links between the nature and the society, there come in front spatial consequences as a result of human activities, rather than the effects as consequence of relation between individuals in terms of fulfilling the basic needs. Between the individual and space of living and fulfilling the basic needs many ties can be established. In social geography we have documented economical impact on humans (work and supply).

The consequences of human acting are differently reflecting in the landscape (space). In social geography, there have been well researched demographical regions, the regions of daily migrants, socio-economical territories. Nevertheless, there is a lack of knowledge about the regions appearing as a result of the influence of the different social institutions, the media, the organized public life, the regional belonging - activities that are revealing links between the living and acting of society to that space. Such links definitely exist 
and are expressing themselves in notion such as regional consciousness, the feeling of regional belongingness, the regional identity, the territory and identity region. The topic on what all those links are based, how are they manifested, which connections between the individual and the space they have is for now poorly researched.

Regional identity is a phenomenon that includes both the objective (nature, economy) and the subjective (individual and collective images) characters. It is consisted of three important levels: the cognitive, the emotional and the instrumental.

We can look on the appearance of regional identities from objective and subjective point of view. Through the objective point of view, we can research the regional identities as the different form of social act often placed in some social organization (institution) having influence on regional consciousness. Through the subjective perspective, we are approaching the point of view of the society (social groups) that is based on the values, the norms, the symbols, the tradition and the feeling of belonging to the same space of living. The double point of view come from the double structure of society. On the one side we have the organizations and the systems of social life creating a specific social structure. On the other hand we have the community and the individual. From different sources we can find out that in the modern world, the social institutions, the media, the administrative organizations, the economy subjects and the massive sports are playing the key role in the terms of establishment and preserving the regional identity. There are also traditional factors as the landscape, the history, the culture, the language and the dialect.

The regional identity is not a theoretical construct only but a realistic appearance with the consequence on many fields of the human existence. To find out the regional belonging, we carried out an interview. We found out that the feeling of belonging is not only the emotional relation but a very concrete relation between the people and their own environment. It reflects through the participation of different common affairs. And if negative initiative from the state comes people are firmly convinced, they will hinder them if they do not agree.

In the paper we tried to show that the regional identity influences on the activation of a creative potential of citizens and can quite often initiate intervention of the state. This applies to the administrative divisions - regionalization can be less conflicted by respecting the opinion of the people. It turned out that one of the issue of the appearance of the regional identity, especially through spatial range of identical factors, identity regions can be recognized. 